\title{
Aplikasi Prediksi Tingkat Kesembuhan Covid Di DKI Jakarta Dengan Metode Exponensial Smoothing
}

\author{
Aprizal Setiawan ${ }^{1, *}$, M. Iwan Wahyuddin ${ }^{2}$, Deny Hidayatullah ${ }^{3}$ \\ ${ }^{1,2,3)}$ Universitas Nasional, Jl. Sawo Manila, Pejaten Ps. Minggu Jakarta 12520Informatika, \\ Fakultas Teknologi Komunikasi dan Informatika \\ email : ${ }^{* 1}$ aprizalsetiawan900@gmail.com, ${ }^{2}$ iwan.wahyuddi@ civitas.unas.ac.id, \\ deny@civitas.unas.ac.id
}

\begin{abstract}
During the Covid-19 pandemic, many attempts have been made to predict cases of additionalpatients, deaths and other medical indicators using various methods. Several forecast projects as well as predictions have influenced policies in several regions including DKI Jakarta. However, forecasts or predictions for the Covid-19 pandemic are uncertain. On this occasion, I predicted the cure for Covid-19 using the Exponential Smoothing method. This method is a moving average forecasting method that gives weight exponentially or stratified to the data, so that thelatest data will get a greater weight. The monitoring results obtained from this study amounted to 0.89 or $89 \%$ for the cure rate and 0.64 or $64 \%$ for the mortality rate. With this method, it can make it easier to see the progress of the Covid-19 cure rate.
\end{abstract}

Keyword - Data Science, Exponential Smoothing, Covid-19.

\begin{abstract}
Abstrak - Selama pandemi Covid-19, sudah banyak upaya yang dilakukan untuk meramalkan kasus penambahan pasien, kematian serta indikator medis lainnya dengan berbagai metode. Beberapa proyek prakiraan serta prediksi telah mempengaruhi kebijakan di beberapa daerah termasuk DKI Jakarta. Namun, prakiraan maupun prediksi pandemi Covid-19 pada dasarnya adalah tidak pasti. Pada kesempatan ini saya melakukan prediksi kesembuhan Covid-19 denganmenggunakan metode Exponensial Smoothing. Metode ini suatu metode peramalan rata-rata bergerak yang memberikan bobot secara eksponensial atau bertingkat pada data-data terbarunya sehingga data-data terbaru akan mendapatkan bobot yang lebih besar. Hasil pantauan prediktif yang didapat dari penelitian ini adalah sebesar 0,89 atau 89\% untuk tingkat kesembuhan serta 0,64 atau 64\% untuk tingkat kematian. Dengan metode ini dapat mempermudah melihat perkembangan tingkat kesembuhan Covid-19.
\end{abstract}

Kata kunci - Data Science, Penghalusan Exponential, Covid-19.

\section{PENDAHULUAN}

Penyebaran virus COVID-19 yang telah berlangsung sampai saat ini mengakibatkan kelumpuhan dibanyak sektor. Tidak hanya menyebar didaerah asal mulanya yakni Wuhan, Tiongkok, namun wabah ini sudah menjadi pandemi diseluruh belahan bumi. Pada umumnya virus mengalami siklus yang tetap seperti grafiklonceng, dengan durasi tertentu akan mengalamititik puncak dan kembali melandai hinggamengalami penurunan. Namun hal ini berbeda dengan virus COVID-19.

Siklus yang dialami selalu berubah ubah, tidak mudah diprediksi kapan berakhirnya. Telah banyak parapeneliti diberbagai wilayah atau Negara yang telah melakukan upaya prediksi untuk mengetahui tren perkembanganvirus ini dengan menggunakan model berbasis data. Banyak diantaranya fokus pada prediksi penambahan kasus, mitigasi pencegahan, puncak penyebaran hingga kematian. Melakukan prediksi berdasarkan data sangat berartidan begitu diharapkan. Hal ini disebabkan karena secara nyata kita dihadapi ketidakpastian kapan 
berakhirnya pandemi ini. Meskipun hal inimenjadi begitu sulit untuk melakukan prediksi secara akurat, baik dan dapat dipercaya, tetapi hal ini tidak berarti analisis dan prediksi objektif berdasarkan sains dan data sama sekali tidak berguna. Sebaliknya pola pikir tradisional untukoptimalitas danakurasi dalam pemodelan dan prediksi harus dihindari dalam konteks ini. Jurnal ini di tulis berdasarkan eksperimen pengolahan data untuk menghasilkan prediksi perkembangan tingkat kesembuhan COVID-19 khususnya di negara Indonesia daerah DKI Jakarta.Kami berasumsi bahwa perkembangan virus ini dapat di tekan dengan adanya intervensi pemerintah serta perbaikan pola hidup masyarakat dan disampingkan dengan edukasi. Dalam penelitian ini menerapkan sistem "prediksi tingkat kesembuhan" dengan metodeexponensial smoothing untuk memberikan halpositif untuk warga Negara Indonesia khusus nya DKI Jakarta. Setiap perubahan prediksi yang terjadi bukan berarti sebagai kesalahan atau ketidakakuratan, tetapi sinyal berharga dari perubahan dalam skenario dunia nyata yang sangat sulit dikenali. Prediksi yang dihasilkan akan menginformasikan, serta tindakan agar menjadi keputusan pemerintah Indonesia untuk menentukan kebijakanNew Normal” dimasa depan.

\section{METODE PENELITIAN}

Fajar Adi Kusumo, Nanang Susyanto (2020) dengan judul "Model Berbasis SIR Dalam Prediksi Awal Penyebaran Covid-19 di Daerah Istimewa Yogyakarta [1]. Hary Sabita, Riko Herwanto (2020)dengan judul "Pantauan Prediktif Covid-19 DenganMenggunakan Metode SIR dan Model Statistik Di Indonesia". [2]. Sulantari Sulantari, Wigid Hariadi (2020) dengan judul "Analisis Survival Waktu SembuhPasien Covid-19 diKabupaten Banyuwangi”. [3]. Muhammad Irfan Syuhudi (2020) dengan judul "Tubuh-Tubuh Yang Patuh: PengalamanPasien Sembuh Covid-19". [4]. Glisina Dwinoor Rembulan, Tony Wijaya (2020) dengan judul "Kebijakan Pemerintah Mengenai Covid-19 di Setiap Provinsi di IndonesiaBerdasarkan Analisis Klaster". [5]. Widya Rahmadani,Sagita CharolinaSihombing (2020) dengan judul "AnalisisPenyebaran Virus Covid- 19 di Provinsi SumateraSelatan Menggunakan Metode InterpolasiLagrange". [6]. Alif Oki Harfiansyah, Deni Arifianto, Qurrota A'Yun (2020) dengan judul "Model Berbasis SEIR Dengan Metode Runge Kutta Fehlberg Ordo 10 Dalam Prediksi Awal Penyebaran Covid19 di Provinsi DKI Jakarta Dengan Aplikasi MATLAB”. [7].

\section{Flowchart Exponensial Smoothing}

Pada penelitian ini membutuhkan suatu alur atau proses logic yang sering disebut dengan flowchart, yang bertujuan untuk merancang alur logika pada suatu sistem untuk menuntaskan masalah. Terdapat beberapa alur metode pada setiap perhitungan. Pada flowchart akan diuraikan bagaimana kalkulasi pada setiap metode hingga menemukan hasil. Ada beberapa alur atau struktur yang akan dihitung yaitu, DoubleExponential Smoothing HolP. Seperti pada gambar 1 sampai 4. [8]. 


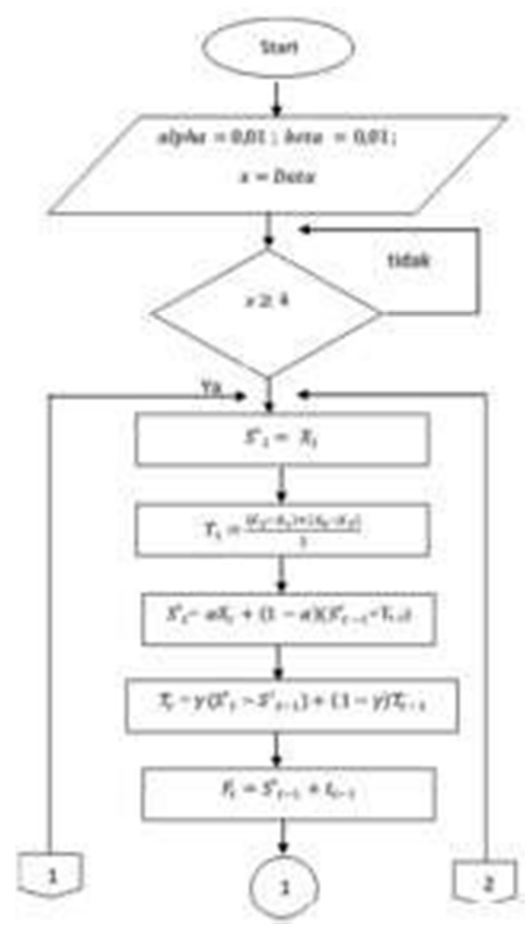

Gambar 1. Alur Pertama

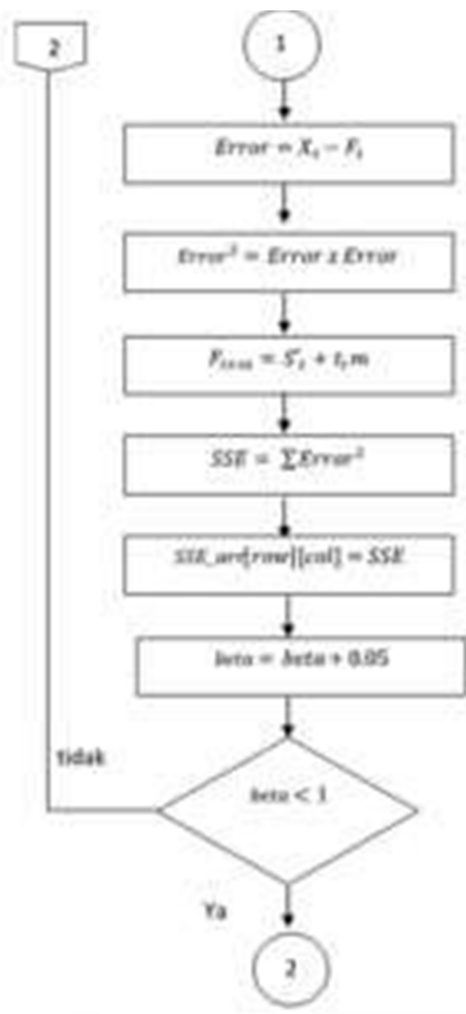

Gambar 2. Alur Kedua 


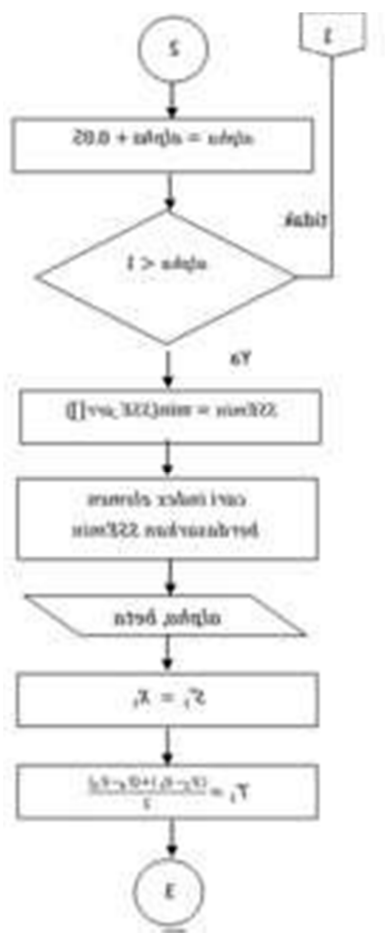

Gambar 3. Alur Ketiga

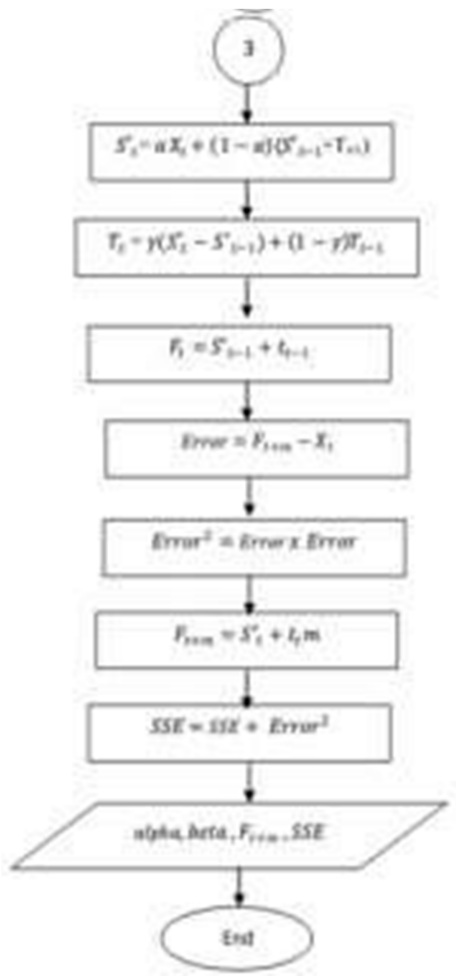

Gambar 4. Alur Akhir 


\section{Ketersediaan (Availability)}

Ketersediaan atau Availability merupakan probabilitas suatu sistem bahwa sistem yang bekerja sesuai dengan komponen yang diperlukan pada sebuah peluang tertentu yang bertujuan untuk menormalkan kondisi. Availability juga dapat ditafsirkan sebagai total estimasi waktu yang spesifik yang diperlukan untuk pemulihan dan perbaikan. Interval pengganti mempengruhi tingkat siapan atau ketersediaan dan perbaikan. Mean Time To Repair (MTTR) adalah salah satu cara pengukuran yang sering digunakan dalam pemulihan. Secara garis besar variabel random dapat berfungsi dalam perbaikan, kejadian yang berulang mengakibatkan perbedaan pada waktu perbaikan [9].

\section{Metode Exponential Smoothing}

Metode Smoothing exponential adalah suatu teknik atau prosedur peramalan yang rata-rata bergerak dengan pembobotan dan perbaikan secara berulang pada objek yang diamati, yang dititik beratkan pada metode peramalan. Pengurangan prioritas kuantitas pada objek yang diamati lebih tua. Terdapat lebih dari satu parameter dalam suatu exponential smoothing. Yang menentukan hasil dan explisit dengan melakukan pendalaman untuk menetapkan bobot pada suatu nilai. Dengan begitu, prioritas yang lebih tinggi akan ditentukan pada observasi terbari ketimbang yang lama. Ada beberapa metode dalam Exponential Smoothing.

a. Single Exponential Smoothing (SES)

SES sering digunakan untuk peramalan untuk kurun waktu yang pendek seperti jangka waktu kurang lebih satu bulan. Dengan memprediksi model data yang dinamis di wilayah maen yang konstan, dengan pola trend tang konsisten. Berikut merupakan rumus SES :

$$
F f+1=a * X t+(1-a) * F t
$$

b. Double Exponential Smoothing

DES atau Double Exponential Smoothing merupakan metode yang dimanfaatkan untuk mentukan trend pada pemulusan sederahana. Trend memiliki dua elemen yang harus di perbaharui pada masing-masing periode trand dan levelnya. Tingkat atau level merupakan perkiraan yang dimuluskan dari data nilai pada setiap periode. Dan trend merupakan perkiraan yang diturunkan dari tingkatan nilai akhir pada setiap periode. Berikut adalah rumus DES :

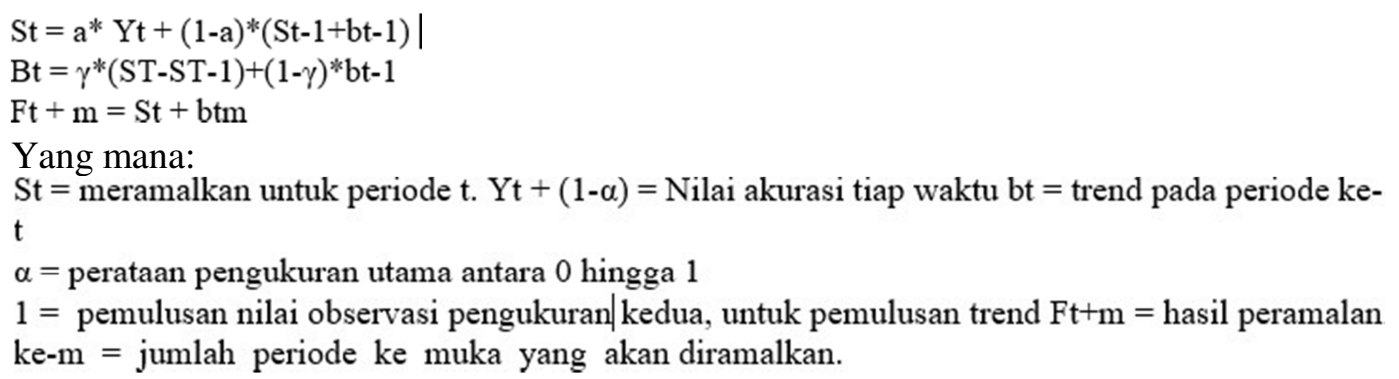

\section{c. Triple Exponential Smoothing}

Ketika data menampilkan trend pada prilaku musiman, maka digunakannya metode TES atau Triple Exponential Smoothing. Metode yang ditemukan oleh Holtn Winters dikembangkan menjadi 3 persamaan pengukuran. Metode ini terbagi menjadi dua tipe musim, pertama Multiplicative seasonal model lalu yang kedua Additive seasonal model. Metode yang dipakai diberbagai jenis data stasioner maupun non stasioner sering digunakan selama data tidak termasuk faktor musiman. Namun jika metode tersebut digunakan untuk meramal data yang termasuk faktor musiman, tapi metode tersebut tidak bisa menangani permasalaham yang kompleks. Walau bgitu, faktor musiman bisa diatasi secara eksklusif. Berikut adalah rumus TES:

Setiawan, et., al [Aplikasi Prediksi Tingkat Kesembuhan Covid Di DKIJakarta Dengan Metode Exponensial Smoothing] 
Pemulusan trend:

$B t=g(S t-S t-1)+(1-g) b t-1$

Pemulusan Musiman:

$I=b t X \mid$

$t S+(1-b) t-L+m$

Ramalan:

$F t+m=(S t+b t m) I t-L+m$

\section{HASIL DAN PEMBAHASAN}

A. Kerangka Penelitian

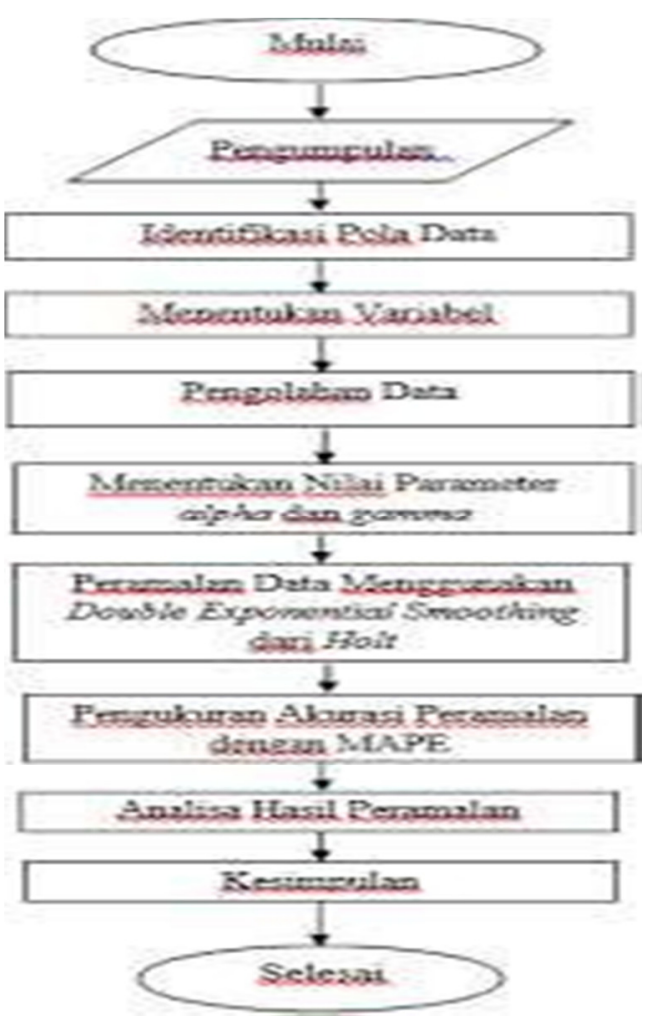

Gambar 5. Flowchart Kerangka Penelitian

Pada gambar flowchart kerangka penelitian di awali dengan tahapan penyiapan elemen yaitu studi literature dari sejumlah sumber jurnal yang akan menjadi acuan untuk implementasi penelitian ini. Pengumpulan data di lakukan untuk prosespencarian data yang di dapat dari berbagai sumber yang akurat dan menentukan variable. Dilanjutkanpengolahan data untuk menentukan nilai parameteralpha dan gamma. Peramalan data menggunakan Double Exponential Smoothing dari Holt. Pengukuran akurasi peramalan dengan MAPE.Analisa hasil peramalan dan diselesaikan dengankesimpulan.

Setiawan, et., al [Aplikasi Prediksi Tingkat Kesembuhan Covid Di DKIJakarta Dengan Metode Exponensial Smoothing] 
B. Metode Exponential smoothing

Expontial Smoothing adalah alur algoritma yang berproses pada berjalannya logika bertujuan untuk menuntaskan masalah. Proses kalkulasi perhitungan dilakukan pada tiap sistem peramalan. Penelitian ini menjelaskan urutan atau alur kalulasi penghitungan pada tiap metode, sehingga hasil akhir dapat didapatkan.

Pemulusan pada metode eksponensial linier memiliki dasar dan prinsip yang sama dengan Brown, namun metode ini tidak melakukan kalkulasi pemulusan ganda secara langsung. Maka nilai yang dihasilkan trend dengan pengukuran lain dari 2 pengukuran yang terdapat pada hasil akhirnya. Digunakan 3 ramalan pemulusan eksponensial linier Holt :

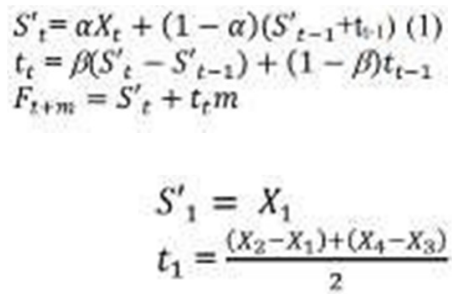

Inialisasi :

Metode Exponential smoothing dipakai saat adanya data trend permulusan yang sederhana, terkecuali bila 2 bagian harus diperbarui pada tiap tingkat period trendnya. Tingkat atau level merupakan estimasi nilai data yang akhirnya dimuluskan pada tiap period. Dan trend merupakan estimasi nilai yang rata-rata dihaluskan pada perkembangan dari setiap period akhir.

\section{Single Exponential Smoothing}

Metode ini digunakan untuk melakukan peramalan dengan besaran alpha $(\alpha)$ yang diimplementasikan yaitu $0.1,0.5$, dan 0.9 . forecast error adalah hasil yang diramalkan. Penerapan metode ini digunakan untuk mendeteksi dan memastikan fluktuasi kesembuhan pasien yang meninggal, yaitu menetapkan $\alpha$ (alpha) dengan besaran :

$$
\begin{aligned}
& =(0.1 \times 499)+(1-0.1) 459 \\
& =49,9+413,1 \\
& =463
\end{aligned}
$$

Penerapan DES Holt pada perkalkulasi metode source code, berikut adalah tahapan pada metode perhitungan:

1. Persiapan yang dilakukan untuk kalkulasi data histori

2. Melakukan Menggunakan dua pengukur berbeda untuk melakukan penilaian pengukuran dengan menentukan range $1<$ (a) $>0$ hingga $1<$ (b) $>0$ sehingga pemasangan dan oenentuan pengukuran bisa menghasilkan range yang bebas pada kalkulasi inialisasi

3. Persamaan yang dihitung pada inialisasi

4. Menganalisis perhitungan

5. Menggunakan rumus persamaan untuk melakukan perhitungan inialisasi

A. Teknik Pengumpulan Data

Dalam penenelitian ini ada beberapa tahap yang diterapkan :

1. Studi pustaka : dengan melakukan studi literatur, yaitu pengumpulan dan pembelajaran literatur padabuku, artikel dan jurnal.

2. Wawancara : yaitu melakukan wawancara informal. Dengan melakukan wawan cara pakar tanpamemiliki pedoman atau struktur pertanyaan yang objektif. 
B. Pengolahan Data dan Informasi

Dalam pengolahan data ini dibutuhkan sebuah variable yang digunakan sebagai input. Berikutnya dijelaskan tentang konsep metode pengolahan data menggunakan system prediksi kesehatan danexponensial smoothing sehingga menghasilkantujuan penelitian yang sesuai.

C. Analisis Aktual Prediktif

Analisa pantauan prediktif dengan mengambil sampel yaitu di DKI Jakarta. Dengan menggunakan rentan waktu 15 Hari pada 13 Juni 2021. Jumlah penambahan kasus terbanyak pada bulan ini untuk Propinsi DKI Jakarta adalah sebesar 402 data covid. Pada gambar 2 adalah grafik aktual prediksi.
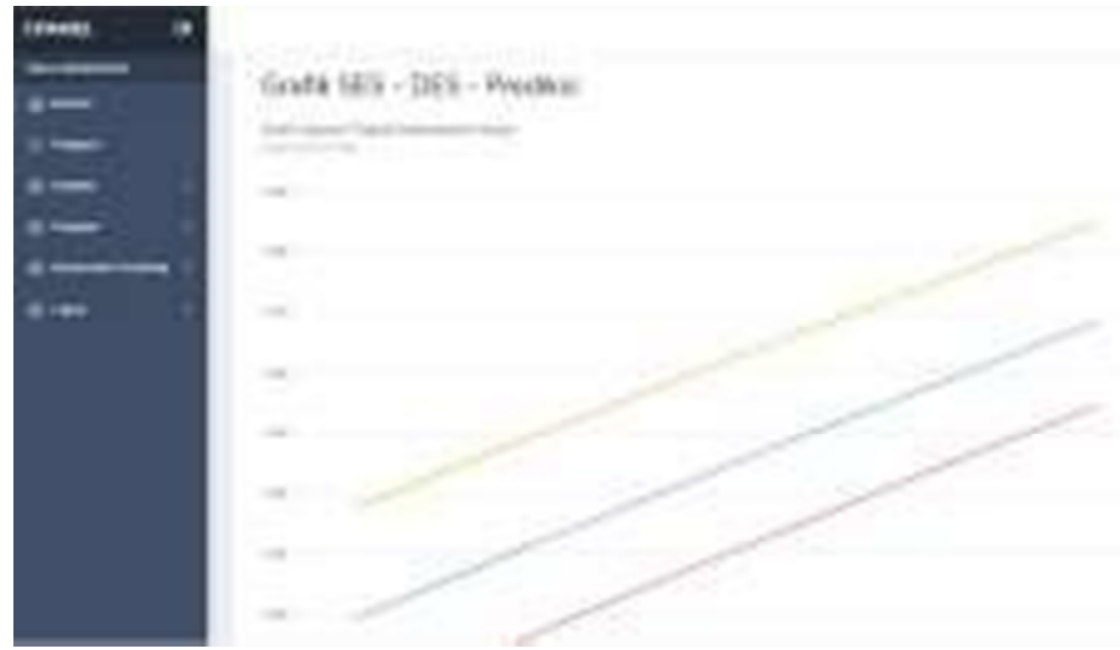

Gambar 6. Grafik Prediksi

D. Pengukuran Akurasi Prediksi

Komperasi dilakukan dalam pengujian akurasi pada hasil kalkulasi program dengan nilai yang sudah terinput pada basis data. Kemudia sistem akan menguji prosedur yang sesuai dengan kriteria tertentu, maka secara otomatis perhitingan akan dilakukan sesuai metode
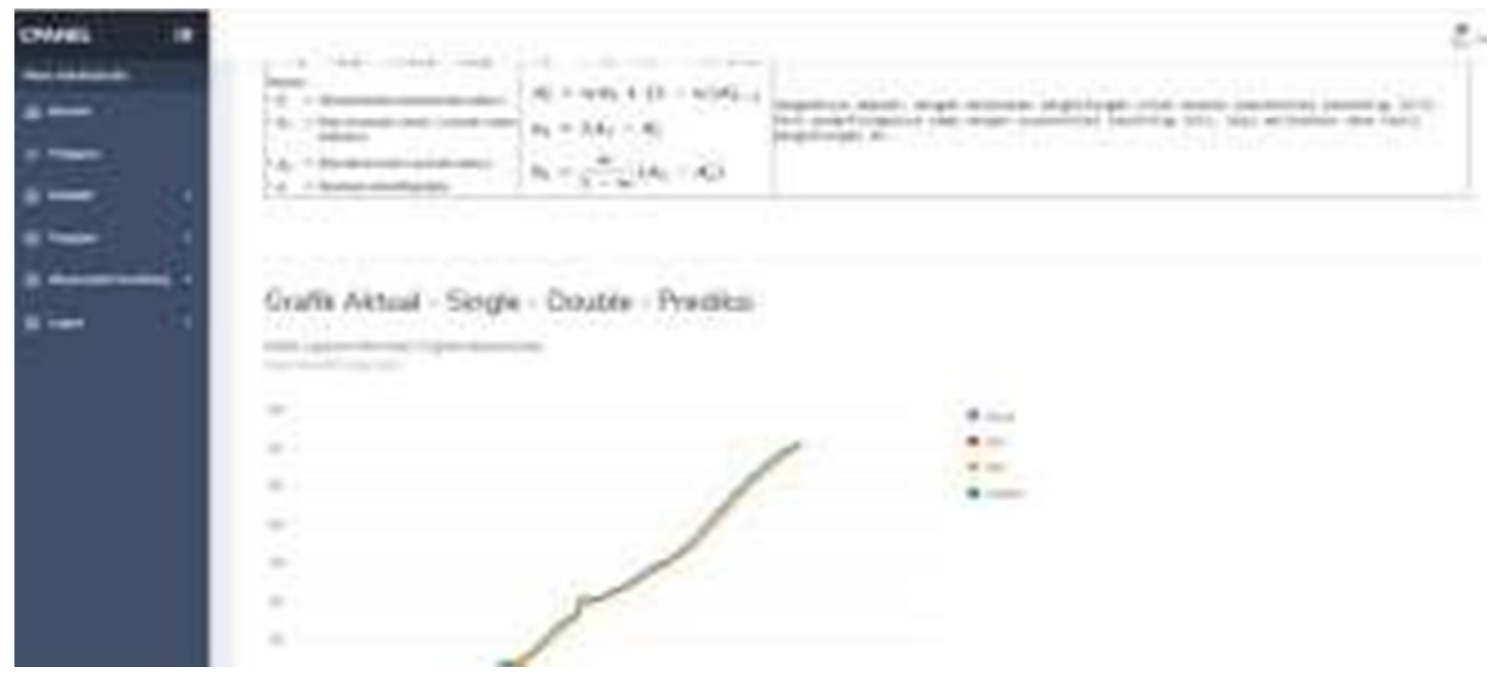

Gambar 7. Grafik Aktual Prediksi

Setiawan, et., al [Aplikasi Prediksi Tingkat Kesembuhan Covid Di DKIJakarta Dengan Metode Exponensial Smoothing] 
E. Hasil pengujian Metode Double Exponential Smoothing Holt

Penulis melakukan pengujian terhadap tingkat keksembuhan dan kematian, jumlah data yang digunakan sebagai data histori. Nilai kesembuhan dan kematian didapat dari perhitungan selisih dari data asli dengan data peramalan yang dihasilkan, sehingga dapat mengetahui nilai penyimpanyan dalam bentukpersen. Pengujian ini juga memprediksi tingkat kesembuhan dalam jangka waktu 15 hari, penelitian berproses secara dinamis sesuai dengan SES terkecil yang dihasilkan. Pada gambar 4 dan 5 menunjukan data kesembuhan.

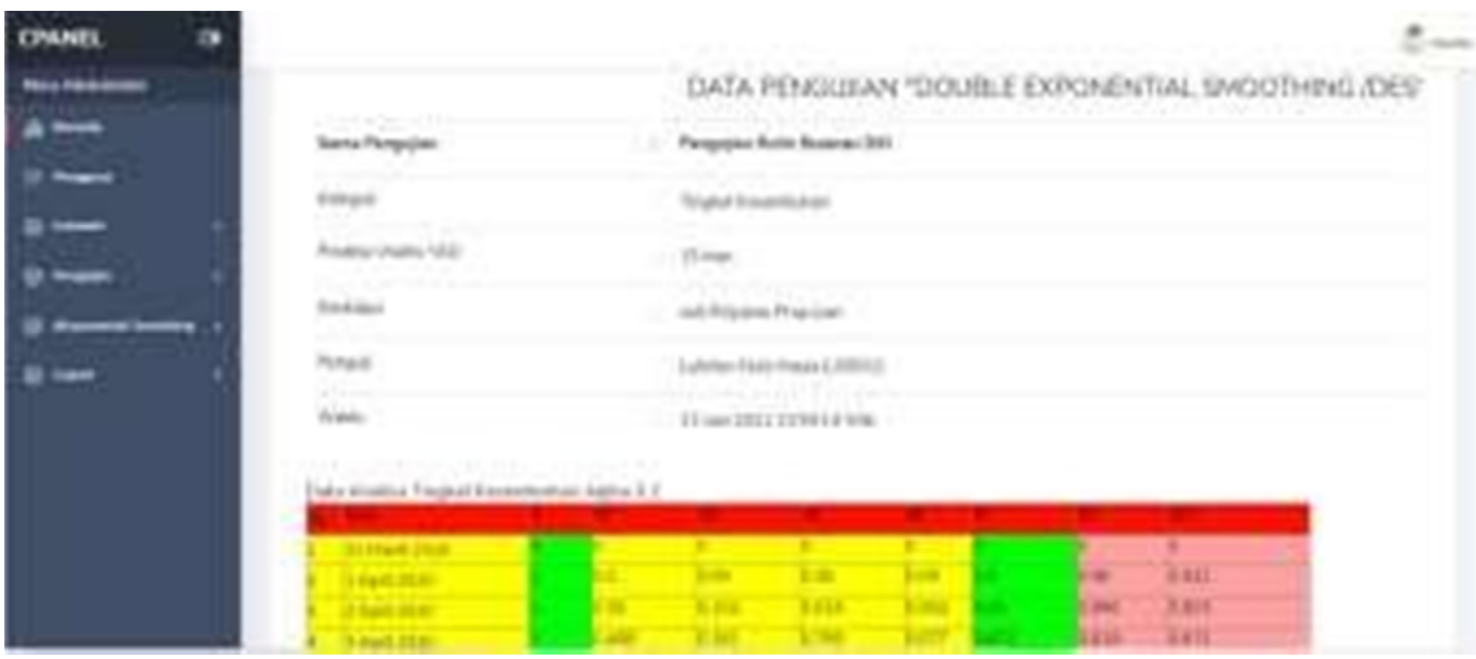

Gambar 8. Data Kesembuhan
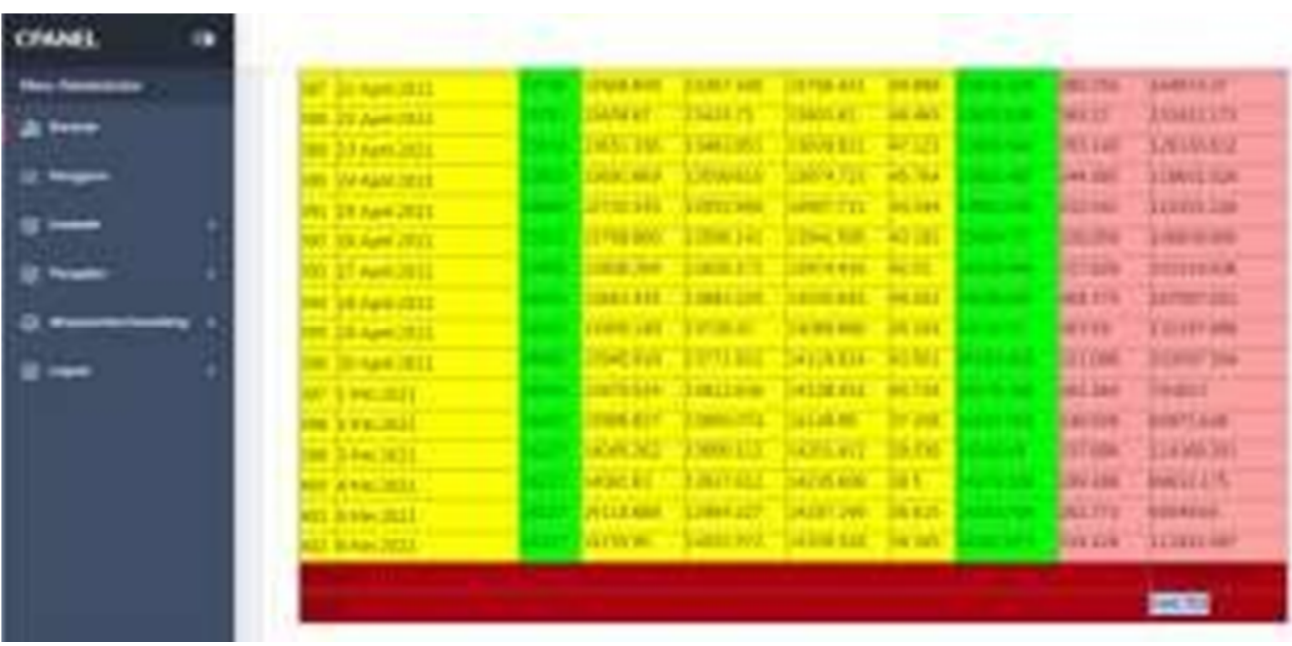

Gambar 9. Data Kesembuhan

Data tingkat kematian pada kasus covid pada prediksi waktu 15 hari, terlihat pada gambar 


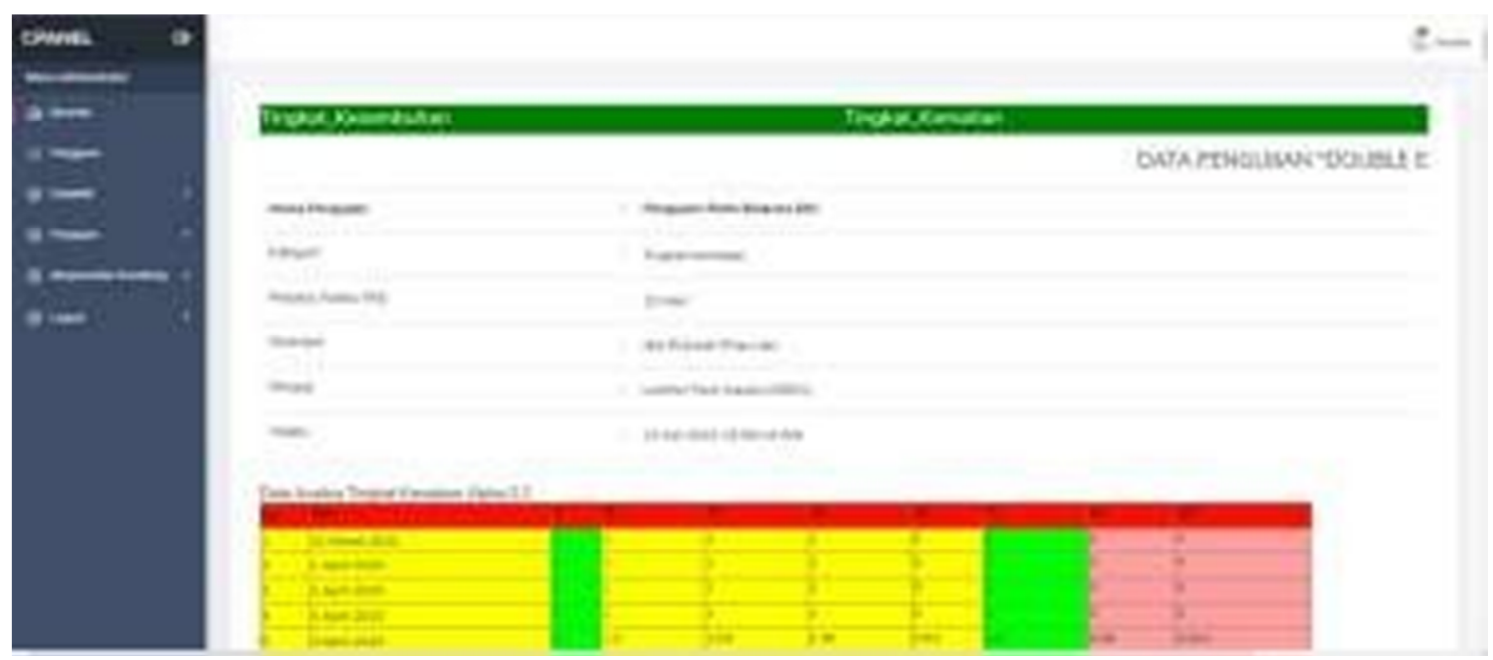

Gambar 10. Data Kematian

\section{KESIMPULAN}

Berdasarkan hasil analisa data yang kami lakukan, terlihat bahwa perubahan perkembangan dan penyebaran virus COVID-19 ini memiliki pola berbeda dari virus lain yang memiliki siklus dan fase yang tetap seperti pada umumnya. Perilaku sehat dan intervensi pemerintah dalam bentuk kebijakan seperti pembatasan sosial, menggunakan masker dan protokol lainnya menjadi faktor dalam penting dalam penekanan laju virus ini. Dari hasil analisa prediksi yang didapatkan pada salah satu Provinsi yaitu DKI Jakarta diperoleh tingkat kesembuhan mencapai nilai 0,89 atau setara dengan $89 \%$, sementara tingkat kematian sekitar 0.64 atau setara dengan $64 \%$.

\section{SARAN}

Data yang diperoleh tentu saja masih banyak kekurangan, terlebih dengan banyaknya data kosong yang hampir mencapai $2 \%$ dari total keseluruhan. Kedepannya penulis berharap penelitian ini dapat diteruskan dengan menambah sumber data, agar hasil prediksi bisa lebih akurat.

\section{DAFTAR PUSTAKA}

[1] Fajar Adi Kusumo dan Nanang Susyanto, 2020. "Model Berbasis SIR Dalam Prediksi Awal Penyebaran Covid-19di Daerah Istimewa Yogyakarta,” Vol. 02, No. 01,

[2] Hary Sabita dan Riko Herwanto, "Pantauan Prediktif Covid-19 Dengan Menggunakan Metode SIR dan Model Statistik di Indonesia,” Vol. 14, No. 02, Hal. 145-150, Desember, 2020. 
[3] Sulantari dan Wigid Hariadi, 2020. “Analisis Survival Waktu Sembuh Pasien Covid-19 di Kabupaten Banyuwangi," Vol. 04, No. 02,

[4] Muhammad Irfan Syuhudi, 2020. "Tubuh-tubuh yang Patuh: Pengalaman Pasien Sembuh Covid-19," Vol. 06,No. 02,

[5] Glisina Dwinoor Rembulan dan Tony Wijaya, "Kebijakan Pemerintah Mengenai Covid-19 di Setiap Provinsi di Indonesia Berdasarkan Analisis Klaster,” Vol. 13, No. 02, hal. 7486, Agustus, 2020.

[6] Widya Rahmadani dan Sagita Charolina Sihombing, "Analisis Penyebaran Virus Covid19 di Provinsi Sumatera Selatan Menggunakan Metode Interpolasi Lagrange,” Vol. 02, No. 01, hal. 12-23, Juli, 2020.

[7] Alif Oki Harfiansyah, Deni Arifianto, dan Qurrota A'Yun. 2020, "Model Berbasis SEIR Dengan Metode Runge Kutta Fehlberg Ordo 10 Dalam Prediksi Awal Penyebaran Covid-19 di Provinsi DKI Jakarta Dengan Aplikasi Matlab." http://repository.unmuhjember.ac.id/8814/10/j.\%20 ARTIKEL.pdf

[8] Petropoulos F., M. S. 2020. Forecasting The Novel Corona Virus COVID-19. Plos ONE, 15.

[9] Murray, C. J. 2020. Forecasting The Impact of The First Wave of The COVID-19 Pandemic on Hospital Demand and Deaths for The USA and European Economic Area Coubtries. MedRxiv.

[10] Organización Mundial de la Salud, "Advice on The Use of Masks In The Context of COVID-19: Interimguidance-2,” Guía Interna de la OMS, No. April, pp. 1-5, 2020.

[11] Raharja, dkk. 2010. Penerapan Metode Exponensial Smoothing Untuk Forecast Penggunaan Waktu Telepon di PT. Telkomsel Divre3 Surabaya. Jurnal Sistem Informasi. 